Potravinarstvo Slovak Journal of Food Sciences vol. 13, 2019, no. 1, p. 1013-1017

https://doi.org/10.5219/1199

Received: 19 September 2019. Accepted: 12 December 2019. Available online: 28 December 2019 at www.potravinarstvo.com (C) 2019 Potravinarstvo Slovak Journal of Food Sciences, License: CC BY 3.0 ISSN 1337-0960 (online)

\title{
RURAL PRODUCTION OF TROPICALLY ADAPTED BREEDS OF CHICKENS IN RURAL AREAS OF KWARA STATE, NIGERIA
}

\author{
Olayinka Alabi, Ayoola Shoyombo, Segun Jegede, Olarewaju Oluba, Oghenerobor Akpor
}

\begin{abstract}
Chicken keeping is a common thing with most household in rural areas of Nigeria. The birds are raised under extensive system of production with little or no feed provided by the farmers for the birds, hence there is the need to compare the rate of egg production of six different breeds of chickens reared under the same conditions in the rural areas. Twelve villages were randomly selected from the long list of villages in Kwara, 20 households per village and 4 villages per senatorial district, with a total coverage of 240 households for the study. The birds that were used for the study were indigenous chicken (Fulani), improved indigenous chickens (Shika Brown, Funaab Alpha and Noiler) and imported tropically adapted birds (Sasso and Kuroiler). Thirty six weeks old pre-vaccinated and brooded chickens of different breeds given to the farmers were managed under the traditional poultry scavenging system in all the three senatorial districts. The nonparametric Kruskal-Wallis test was used for the comparison between districts and breeds. There were no significant differences in egg production per senatorial district, egg production from different breeds and production from different senatorial districts remained averagely low. Low egg production by all the breeds showed that scavenging way of rural chicken production should be improved on for better productivity. This can be achieved through supplemental feed formulated and produced from locally available feed ingredients for the chickens.
\end{abstract}

Keywords: breeds; chickens; egg; production

\section{INTRODUCTION}

The demand for meat and egg is on the increase as a result of increase in the rate of population growth worldwide. Notably, poultry production development in Nigeria has taken a quantum leap in the last two decades; however, the development has been mainly restricted to commercial poultry production and not rural poultry production. The rural poultry production accounts for about 70 percent of the total poultry population (Ogunlade and Adebayo, 2009; Akinola and Essien, 2011), indigenous chicken eggs and meat has always fetched a much higher price than that from the commercial poultry and also, the products from both rural chickens and commercial birds have been running parallel with their own market segment and specific clientele (Omprakash and Pandian, 2011), yet, indigenous chicken has been totally neglected by both government and the commercial poultry investors.

A systematic and planned development of indigenous chicken production into small commercial units thus holds a tremendous potential for growth in rural areas, especially owing to consumer preference for its egg and meat (Bett et al., 2012). The consumers' preference for indigenous chickens is based on the perception that locally produced poultry products are from natural and safe feed crops and hence good for the family's consumption. Indigenous chickens are considered as valuable asset for rural household and has contributed significantly to food availability for the household. This because, poultry mainly provides meat and eggs which increase households' consumption of animal sourced food. Eggs, however small in quantity provide micronutrients and high-quality protein in bioavailable forms to balance nutritionally the consumption of common staple food that is basically energy-based diet (De Bruyn et al., 2015).

Moreover, the contribution of poultry to food security can be related with income (Magothe et al., 2012; Abebe and Tesfaye, 2017) from sales of poultry and poultry products, which are often, used for purchase of addition food items necessary for the household from the market (Assa, 2012). More so, indigenous chickens are genetically envied for genetic exploration and hybrid vigour exploitation (Adeleke et al., 2011). Indigenous chicken farming is, however, faced with several challenges (Billah et al., 2013), including inherent slow growth rates, high rearing mortalities and susceptibility to diseases, poor housing, insufficient health care (Alders, Bagnol and Young, 2010), high feed cost, poor nutrition and poor layers laying small sized eggs, all these challenges has adverse effect on production (Sharaunga, Darroch and Mudhara, 2014; Ruel, Quisumbing and Balagamwala, 2018). Many improved breeds of broilers have been 
imported into Nigeria and presently, there is an improvement in the potential of broiler strains to provide high quality meat at lower cost. The improved breeds grow faster and produce more meat and eggs than the local breeds. The objective of this study was to compare the rate of egg production of six different breeds of chickens reared under the same conditions in the rural areas.

\section{Scientific hypothesis}

Management practices has direct effect on rate of egg production than breeds of chicken

\section{MATERIAL AND METHODOLOGY}

The study was conducted between December 2017 and April, 2018 within the three Senatorial Districts of Kwara State of Nigeria. Kwara State is located in the North central geopolitical zone, commonly referred to as Middle Belt. The state comprises of rainforest in the Southern parts with wooded savannah covering the larger part of the state. Average maximum temperatures vary between $30{ }^{\circ} \mathrm{C}$ and

$35{ }^{\circ} \mathrm{C}$.

A total of four villages per Senatorial District were selected for the study. In each of the selected villages, twenty households were randomly selected for study, making a total of 240 households. The birds that were used for the study were indigenous chicken (Fulani), improved indigenous chickens (Shika Brown, Funaab Alpha and Noiler) and imported tropically adapted birds (Sasso and Kuroiler), as shown in Figure 1. The distribution of birds in each of the villages were as follows:

- four households with Sasso birds,

- four households with Kuroiler birds,

- three households with Fulani birds,

- three households with Shika Brown birds,

- three households with Funaab Alpha birds,

- three households with Noiler birds.

Thirty-six-week old pre-vaccinated and brooded chickens of different breeds given to the farmers were managed under the traditional poultry scavenging management system. The feeding of birds was supplemented with readily available commercial feeds, agricultural products (maize, rice, sorghum, wheat, millet, etc.), agricultural byproducts (corn bran, wheat bran, rice bran, groundnut cake, etc.) and kitchen wastes (leftover food, leafy vegetables, etc.). Based on the capacity of the farmers, health management practice was also carried out. In handling health challenges, traditional medicine was practiced by the rural resource-poor poultry farmers and this was done by practical application of indigenous medicinal herbs/plant extracts were used in controlling health challenges.

\section{Statistic analysis}

Statistical analysis was carried out using the SPSS Staistical Software. The non-parametric Kruskal-Wallis test was used for the comparison between districts and breeds. Statistical significance was determined at $p$-value of 0.005 (SPSS 2015).

\section{RESULTS AND DISCUSSION}

Indigenous chicken breeds are important in rural economies with respect to income generation and provision of nutritious chicken egg and meat for consumption (Vali 2008; Mahendra, 2016). The system of production adopted in the rural communities affect the availability of these products. The scavenging system of chicken production in the rural area is important (Alders and Pym, 2009) and cheap for the farmer but results in low productivity in terms of body weight gain and egg production (Natukunda et al., 2011). The interview conducted revealed that the farmers gave their chickens a handful of grain early in the morning and evening as supplementary feed but not compounded balanced diet. A Kruskal Wallis One Way ANOVA tests revealed that there was no significant difference in the total number of eggs produced in the senatorial districts (Table 1). However, egg production was observed to be significantly higher in the local breeds than the imported birds (Table 2).

Kruskal Wallis One Way ANOVA tests gives a probability of 0.000 which implies a significant difference in total number of eggs produced in the breed categories. From this result, the Noiler breed has superior and better performance in egg production, followed by Shika Brown, Kuroiler and Sasso. The breeds with least egg production were the Fulani and Fuuaab Alpha (Table 3).

A comparison of egg production of the breeds across the senatorial districts showed that the rate of egg production by the improved indigenous chickens (Noiler and Shika Brown) were higher than the imported chickens (Sasso and Kuroiler) as shown in Figure 2. From the study, egg productivity from different breeds and senatorial districts remained averagely low for each of the districts and this is largely due to poor management practices of birds scavenging on their own for feed with little or no supplementary feed (Turk, 2013; Tadelle and Ogle, 2001), consequently, low and poor feed intake will result in low output productivity even with improved breeds of chickens. Hence performance of birds reared in the rural areas can be improved by change in husbandry, feeding, and better health cover (Fiorella et al., 2016). Another factor responsible for low production is that most of the rural chicken producers do not have the mindset of rearing of chickens for profit making (Dumas et al., 2016) most of the rural chicken producers raise chickens for consumption, entertainment of visitors during festive periods, dowry payment or to give as gift but not as a viable business (Melesse, 2014; Dhaka et al., 2017).

The result on egg production per breed shows that noiler breed has superior and better performance in egg production when raised under scavenging system of poultry management. The production of eggs by Sasso and kuroiler chickens were low compared to Noiler, an improved tropically adapted indigenous chicken. This could be due to inappropriate feeding regime and poor management practices (Varguez-Montero et al., 2012) which led to the low laying performance of the imported chickens that are known to have good laying ability (Javed et al., 2003). The scavenging system without adequate supplementary feed is a major contributory factor to low egg production even with breeds that has better genetic potential for growth and production. 
Potravinarstvo Slovak Journal of Food Sciences

Table 1 Egg Production in the senatorial districts $(n=2132)$.

\begin{tabular}{lccccc}
\hline \multirow{2}{*}{ Senatorial District } & \multirow{2}{*}{$\begin{array}{c}\text { No. of } \\
\text { Collection Point }\end{array}$} & Mean & Total Eggs & \multicolumn{2}{c}{ 95\% Confidence Interval for } \\
\cline { 3 - 6 } & & & & Mean \\
\hline Kwara Central & 478 & 12.87 & 6154 & 10.19 & 15.56 \\
Kwara North & 481 & 7.57 & 3642 & 6.65 & 8.49 \\
Kwara South & 1173 & 11.66 & 13676 & 10.53 & 12.79 \\
\hline Total & 2132 & 11.01 & 23472 & 10.12 & 11.90 \\
\hline
\end{tabular}

Note: Kruskal Wallis Value $=0.329$, Degree of Freedom $=2, p$-value $=0.848$.

Table 2 Egg production of imported and local breeds $(n=2132)$.

\begin{tabular}{lccccc}
\hline Breed & $\begin{array}{c}\text { No. of } \\
\text { Collection } \\
\text { Point }\end{array}$ & Mean & & Total Eggs & \multicolumn{2}{c}{$\begin{array}{c}\text { 95\% Confidence Interval for } \\
\text { Mean }\end{array}$} \\
\cline { 3 - 6 } & 796 & 9.76 & 7771 & Lower & Upper \\
\hline Imported & 1336 & 11.75 & 15701 & 10.45 & 10.87 \\
Local Breed & 2132 & 11.01 & 23472 & 10.12 & 11.90 \\
\hline Total & 218.049, & & & 13.01 & \\
\hline
\end{tabular}

Note: Kruskal Wallis Value $=218.049$, Degree of Freedom $=5, p$-value $=0.000$.

Table 3 Egg production per breed $(n=2132)$.

\begin{tabular}{llllll}
\hline \multirow{2}{*}{ Breed } & $\begin{array}{l}\text { No. of } \\
\text { Point }\end{array}$ & Collection & Mean & Total Eggs & \multicolumn{2}{c}{$\begin{array}{l}\text { 95\% Confidence Interval for } \\
\text { Mean }\end{array}$} \\
\cline { 4 - 6 } & & & & Lower & Upper \\
\hline Fulani & 342 & $5.70^{\mathrm{c}}$ & 1950 & 4.59 & 6.82 \\
Sasso & 356 & $10.31^{\mathrm{b}}$ & 3671 & 8.63 & 11.99 \\
Noiler & 212 & $31.03^{\mathrm{a}}$ & 6579 & 25.58 & 36.48 \\
Kuroiler & 440 & $9.32^{\mathrm{b}}$ & 4100 & 7.84 & 10.80 \\
Shika Brown & 446 & $12.36^{\mathrm{b}}$ & 5512 & 10.41 & 14.31 \\
Funaab Alpha & 336 & $4.94^{\mathrm{c}}$ & 1660 & 3.59 & 6.29 \\
\hline Total & 2132 & 11.01 & 23472 & 10.12 & 11.90 \\
\hline
\end{tabular}

Note: $\mathrm{n}=2132$, Kruskal Wallis Value $=218.049$, Degree of Freedom $=5, p$-value $=0.000$.

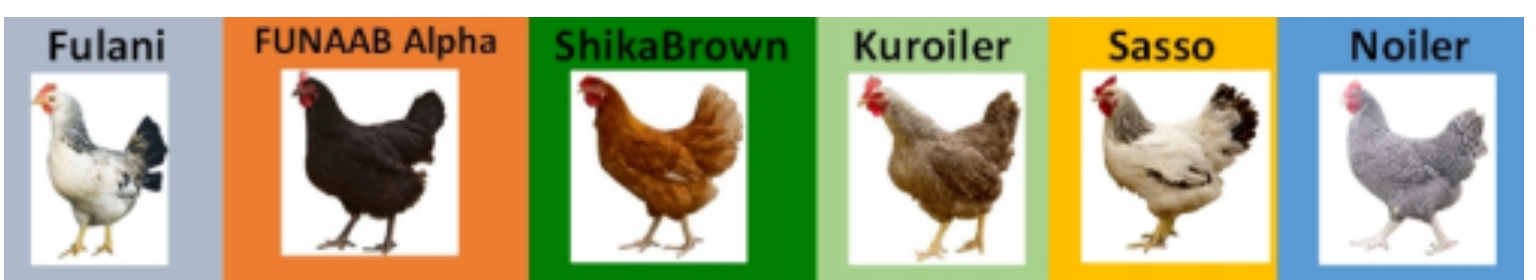

Figure 1 The chicken breeds used for the study (Adebambo et al., 2018).

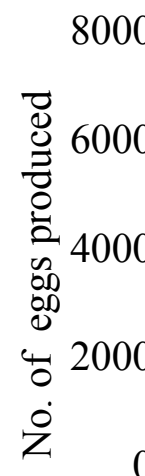

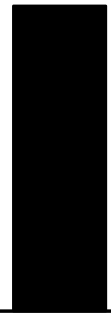

Kwara Central

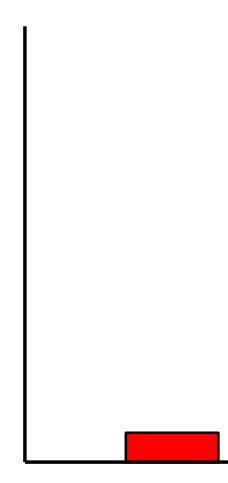

Kwara North

Senatorial Districts

Imported breed

Improved indigenous breed

Figure 2 Egg production of the imported and improved indigenous breeds. 
Mutayoba et al., (2012) reported that supplementation can lead to improved performance of local chickens in terms of growth, egg production and quality.

The cost and availability of commercial feed influenced its use by people of low resources in the rural areas however, supplementary feed can be compounded from locally available feed ingredients in the rural areas. It is of importance that scavenging system must be supplemented either with compounded feed or left over meal from individual household.Left over meals can only be possible where the household has more than enough to eat but in situations where there are no leftovers as a result of poverty or food scarcity, it will have negative effect on the chickens resulting in low body weight and egg production (Gondwe et al., 2005).

Another factor that may be responsible for this low egg production by the imported chickens may be adaptability problem. The variation in temperatures, high humidity, excessive heat and rainfall exact significant effects on poultry birds in terms of egg production, body weight, health, diseases, income of farmers, diet of the people, quality and quantity of poultry products and the economy of the developing countries (Tumova and Gous, 2012; Diarra and Tabuaciri, 2014).

Though the six breeds are tropically adapted birds but the rate of adaptability may vary among breeds having effect on the productivity of the chickens. Probably the rate of adaptability may also be reason why noiler birds did better than sasso and kuroiler birds. The performance of any chicken is also affected by genotype and the environment (Dessie et al., 2012), important attributes of indigenous chickens are their hardiness in the ability to tolerate harsh environmental condition and poor husbandry practices in terms of climate, handling, watering, and feeding without much loss in production are all for survivability and not for production as observed in this study.

\section{CONCLUSION}

Low egg production by all the breeds shown in Figure 2 showed that scavenging method of rural chicken production should be supplemented with home formulated feed produced from locally available feed ingredients . Most of the chicken producers in the rural areas do not keep chickens for profit making hence, the need to educate them on improved management system of poultry production. Improved practices will not only increase income level generation but will also bring about positive change in the socio-economic level and food security of the rural communities.

\section{REFERENCES}

Abebe, K., Tesfaye, E. 2017. Poultry based intervention as a tool for rural women empowerment and poverty reduction: a review. Direct Research Journal of Agriculture and Food Science, vol. 5, no. 11, p. 353-359.

Adebambo, O., Adebambo, A., Adeleke, M., Adeleye, A., Adeyinka, I., Ajayi, F., Akinola, W., Alabi, O., Bamidele, O., Dessie, T., Ikeobi, C., Ogundu, U., Ojoawo, H., Osinbowale, D., Ozoje, M., Peters, S., Sonaiya, B., Wheto, M. and Yakubu, A. 2018. Genetic conservation through effective utilization of the improved indigenous chicken breeds by rural households in Nigeria. In Proceedings of the World Congress on Genetics Applied to Livestock Production, Volume
Challenges - Species Conservation, vol. 1117. Nigeria : CGIAR, $17 \mathrm{p}$.

Adeleke, M. A., Peters, S. O., Ozoje, M. O., Ikeobi, C. O. N., Bamgbose, A. M., Olufunmilayo A. A. 2011. Growth performance of Nigerian local chickens in crosses involving an exotic broiler breeder. Trop. Anim. Health Prod., vol. 43, p. 643. https://doi.org/10.1007/s11250-010-9747-3

Akinola, L. A. F., Essien, A. 2011. Relevance of rural poultry production in developing countries with special reference to Africa. World's Poultry Science Journal, vol. 67, no. $4, \quad$ p. $\quad 697-705$. https://doi.org/10.1017/S0043933911000778

Alders, R. G., Pym, R. A. E. 2009. Village poultry: still important to millions, eight thousand years after domestication. World's Poultry Science Journal, vol. 65, no. 2, p. 181-190. https://doi.org/10.1017/s0043933909000117

Alders, R. G., Bagnol, B., Young, M .P. 2010. Technically sound and sustainable Newcastle disease control in village chickens: lessons learnt over fifteen years. World's Poultry Science Journal, vol. 66, no. 3, p. 433-440. https://doi.org/10.1017/S0043933910000516

Assa, M. M. 2012. Poultry production and rural poverty among small-scale farmers in Mzimba District of Malawi. Livestock Research for Rural Development, vol. 24, no. 10, p. 1.

Bett, H. K., Musyko, M. P., Peters, K. J., Bokelmann, W. 2012. Demand for Meat in the Rural and Urban Areas of Kenya: A Focus on the Indigenous Chicken. Economics Research International, vol. 2012, 10 p. https://doi.org/10.1155/2012/401472

Billah, S. M., Nargis, F., Hossan, M. E., Howlider, M. A., Lee, S. H. 2013. Family poultry production and consumption patterns in selected households of Bangladesh. Journal of Agricultural Extension and Rural Development, vol. 5, no. 4, p. 62-69.

De Bruyn, J., Wong, J. T., Bagnol, B., Pengelly, B., Alders, R.G. 2015. Family poultry and food and nutrition security. CAB Review, vol. 10, p. $1-9$. https://doi.org/10.1079/PAVSNNR201510013

Dessie, T., Dana, N., Ayalew,W., Hanotte, O. 2012. Current state of knowledge on indigenous chicken genetic resources of the tropics: domestication, distribution and documentation of information on the genetic resources. World's Poultry Science Journal, vol. 68, no. 1, p. 11-20. https://doi.org/10.1017/S0043933912000025

Dhaka, B. L., Meena, G. S., Bainoa, R. K., Meena, N. L. 2017. Supplementing rural livelihoods through backyard poultry farming. International Journal of Current Microbiology and Applied Sciences, vol. 6, no. 4, p. 14121415

Diarra, S. S., Tabuaciri, P. 2014. Feeding management of poultry in high environmental temperatures. International Journal of Poultry Science, vol. 13, no. 11, p. 657-661. https://doi.org/10.20546/ijcmas.2017.604.172

Dumas, S. E., Lungu, L., Mulambya, N., Daka, W., McDonald, E., Steubing, E., Lewis, T., Backel, K., Jange, J., Lucio-Martinez, B., Lewis, D., Travis, A. J. 2016. Sustainable smallholder poultry interventions to promote food security and social, agricultural, and ecological resilience in the Luangwa Valley. Zambia Food Security, vol. 8, no. 3, p. 507520. https://doi.org/10.1007/s12571-016-0579-5

Fiorella, K. L., Chen, R. L., Milner, E. M., Fernald, L. C. H. 2016. Agricultural interventions for improved nutrition: a review of livelihood and environmental dimensions. Global Food Security, vol. 8, p. 39-47. https://doi.org/10.1016/j.gfs.2016.03.003 
Gondwe, T. N., Wollny, C. B. A., Safalaoh, A. C. L., Chagunda, M. G. G., Chilera, F. C. 2005. Performance of scavenging Malawi local chickens during the period of human food shortage. Livestock Research for Rural Development, vol. 17 , no. 5 , p. 1.

Javed, K., Farooq, M., Mian, M. A., Durrani, F. R., Mussawar, S. 2003. Flock size and egg production performance of backyard chicken reared by rural woman in Peshawar, Pakistan. Livestock Research for Rural Development, vol. 15, no. 11, p. 1.

Magothe, T. M., Okeno, T. O., Muhuyi, W. B., Kahi, A. K. 2012. Indigenous chicken production in Kenya: II. Prospects for research and development. World's Poultry Science Journal, vol. 68, no. 1, p. 133-144. https://doi.org/10.1017/S004393391200013X

Mahendra, K. P. 2016. Importance of Indigenous Breeds of Chicken for Rural Economy and Their Improvements for Higher Production Performance Scientifica, vol. 2016, p. 9. https://doi.org/10.1155/2016/2604685

Melesse, A. 2014. Significance of scavenging chicken production in the rural community of Africa for enhanced food security. World's Poultry Science Journal, vol. 70, no. 3, p. 593-606. https://doi.org/10.1017/S0043933914000646

Mutayoba, S. K., Katule, A. K., Minga, U., Mtambo, M. M., Olsen, J. E. 2012. The effect of supplementation on the performance of free-range local chickens in Tanzania. Livestock Research for Rural Development. vol. 24, no. 5, p. 1.

Natukunda, K., Kugonza, D., Kyarisiima, C. 2011. Indigenous chickens of the Kamuli Plains in Uganda: I. Production system and flock dynamics. Livestoc Research for Rural Development, vol. 23, no. 10, p. 1.

Ogunlade, I., Adebayo, S. 2009. Socio-economic status of women in rural poultry Production in selected areas of Kwara State, Nigeria. International Journal of Poultry Science, vol. 8, p. 55-59. https://doi.org/10.3923/ijps.2009.55.59

Omprakash, A. V., Pandian, C. 2011. Poulvet, 2011. Rural poultry production. Poulvet. Available at: http://poulvet.com/poultry/articles/rural_poultry_production.p hp.

Ruel, M. T., Quisumbing, A. R., Balagamwala, M. 2018. Nutrition-sensitive agriculture: What have we learned so far?. Global Food Security, vol. 17, p. 128-153. https://doi.org/10.1016/j.gfs.2018.01.002

Sharaunga, S., Darroch, M. A. G., Mudhara, M. 2014. The impact of feed costs on the production of eggs in South Africa in period 1970-2007: an analysis using a demand-supply simultaneous equation model. Journal Agrekon, vol. 53, no. 2, p. 83-107. https://doi.org/10.1080/03031853.2014.915484

SPSS. 2015. Statistical Package for Social Scientist, IBM Corp. Released 2015. IBM SPSS, Statistics for Windows, Version 23.0. Armonk. NY: IBM Corp.

Tadelle, D., Ogle, B. 2001. Village poultry production systems in the central highlands of Ethiopia. Trop. Anim. Health Prod., vol. 33, no. 6, p. 521-537. https://doi.org/10.1023/A:1012740832558

Tumova, E., Gous, R. M. 2012. Interaction of hen production type, age, and temperature on laying pattern and egg quality. Poultry Science, vol. 91, no. 5, p.1269-1275.
Turk, J. M. 2013. Poverty, livestock and food security in developing countries. CAB Rev., vol. 8, no. 33, 1 p. https://doi.org/10.1079/pavsnnr20138033

Vali, N. 2008. Indigenous chicken production in Iran: a review. Pakistan Journal of Biological Sciences, vol. 11, no. 22, p. 2525-2531. https://doi.org/10.3923/pjbs.2008.2525.2531

Varguez-Montero, G., Sarmiento-Franco, L., SantosRicalde, R., Segura Correa, J. C. 2012. Egg production and quality under three housing systems in the tropics. Tropical Animal Health and Production, vol. 44, no. 2, p. 201-204. https://doi.org/10.1007/s11250-011-0006-Z

\section{Acknowledgments:}

This study was made possible by International Livestock Research Institute (ILRI) -led by Dr. Tadelle Dessie the International Program Leader for African Chicken Genetic Gains (ACGG), Prof. F.B. Sonaiya the PI. ACGG-NG, Prof. O.A. Adebambo the Co-PI. ACGG-NG and Dr. O. Bamidele, the National Project Coordinator for ACGG-NG.

\section{Contact address:}

*Olayinka Alabi, Landmark University, College of Agricultural Sciences, Department of Animal Science, PMB 1001, Omu-Aran, Kwara State, Nigeria, Tel. $+2348034182256$

E-mail: alabi.olayinka@,1mu.edu.ng

ORCID: https://orcid.org/0000-0002-3257-8144

Ayoola Shoyombo, Landmark University, College of Agricultural Sciences, Department of Animal Science, PMB 1001, Omu-Aran, Kwara State, Nigeria, Tel. +2348036926455 ,

E-mail: shoyombo.ayoola@1mu.edu.ng

ORCID: https://orcid.org/0000-0003-2937-7779

Segun Jegede, Landmark University, Academic Planning UnitOmu-Aran, Kwara State, Nigeria, Tel: +2348160875256,

Email: jegede.segun $@$,lmu.edu.ng

ORCID: https://orcid.org/0000-0002-9973-1377

Olarewaju Oluba, Landmark University, College of Pure and Applied Sciences, Department of Biochemistry, PMB 1001, Omu-Aran, Kwara State, Nigeria, Tel. +23470496639,

E-mail: oluba.olarewaju@1mu.edung

ORCID: https://orcid.org/0000-0002-5107-6959

Oghenerobor Akpor, Landmark University, College of Pure and Applied Sciences, Department of Microbiology, PMB 1001, Omu-Aran, Kwara State, Nigeria, Tel. +2348099189171,

E-mail: akpor.oghenerobor@lmu.edu.ng

ORCID: https://orcid.org/0000-0002-4256-1549

Corresponding author: * 